\title{
Television commercials (TVCs) and its influence on the Buying Decision of the middle-class urban teens of Bangladesh.
}

\author{
Md. Shamsuzzaman \\ Muhammad Ziaulhaq Mamun \\ Md. Ridhwanul Huq \\ Institute of Business Administration \\ University of Dhaka, Bangladesh
}

\section{Key Words}

Buying decision, Preferred TV programs, Television (TV), Television commercials (TVCs), TV watching pattern, TV watching time.

\begin{abstract}
The size of the teenage population is quite large in developing countries (1.6 billion), compared to the developed countries (240 million). The identical trend is also available in Bangladesh where the teenagers are about $21 \%$ of the total population. TV and TVCs have a major influence on the buying decisions of Bangladeshi middle-class teenagers like other developing counties, even with the emergence of digital and social media. As such, the research is focusing on the influence of TVCs in buying decision of the middle-class urban teenagers of Bangladesh. An elaborated multi-step research method including pertinent literature review, expert in-depth interview, focus group discussions and a structured questionnaire survey has been accomplished. Microsoft Excel and SPSS version 21 were used for the analysis of survey data. The study has observed that 95\% of urban teens watch TV either regularly or occasionally, where females were more inclined (97\%) to watch TV than males (93\%). The majority of teens watch TV at night (71\%) and in the evening (21\%). The teens are found to prefer sports the most (41\%) followed by drama serials (29\%). The study has revealed that $89 \%$ of the respondents watch TVCs regularly or occasionally. The study has also explored that $67 \%$ of urban teens are influenced by TVCs to make purchase decisions, while the late teens were more influenced by TVCs (71\%) than the early teens (62\%). Majority of the respondents are fascinated by models or celebrities (65\%) to watch the TVCs. These research findings will assist marketers and business professionals of Bangladesh as well as similar developing countries to target specific teenage segments, types of TVCs, peak hour of airing TVCs and models or celebrity endorsement while prepare cost effective brand communication plan.
\end{abstract}

Corresponding author: $M d$. Shamsuzzaman

Email addresses for the corresponding author: fatherofsaiki@gmail.com

First submission received: $15^{\text {th }}$ September 2018

Revised submission received: $27^{\text {th }}$ February 2019

Accepted: 10 th March 2019

\subsection{The Introduction}

Watching Television (TV) and TV commercials (TVCs) is very much interrelated considering the commercial perspective as well as the entertainment and cognitive tool for the viewers. Bogdanovic (2013) defined television advertisement or commercial (TVA/TVC) as "any paid form of non-personal communication of ideas or products on the electronic media to end user". Even with the emergence of digital and social media, TV and TVCs are still the best tools for brand building particularly for teens of developing countries. Having a high level of interest to be familiarized with a new product or service, teenagers tend to improve their lifestyle and standards of living individually and/or family as a whole. Ahmed, B. (2013) stated in his research finding that advertisements especially TVCs are big marketing weapons to attract teen customers and win their minds. As a result, insights into the teenagers' viewing of TVCs are very much important for marketers, brands builders and researchers.

The size of the teenaged population is quite large in developing countries (1.6 billion), compared to the developed countries (240 million) (PRB 2016). Furthermore, the teenaged population is the major proportion of most of the developing countries' total population (Adiko \& Adjei, 2016). In Bangladesh, 20.5\% of the total

www.jbrmr.com A Journal of the Academy of Business and Retail Management (ABRM) 
population falls within the age group of 10-19 years, of which $21.5 \%$ lives in urban areas (BBS 2011). Precisely in Dhaka, the total number of teen students is 573,599, which is the largest crowd of total teen population till date (BES 2015) and the majority of them comes from the middle-class family. Though teenagers used to play a limited role in the family buying decision, nowadays they have a much dominating position to choose the brands for them and/or their families with the availability of electronics and digital media. Zaltman, G., Dotlich, D. L., \& Cairo, P. C. (2003) revealed in their study that TVCs have significant importance in teenagers' cognitive development which consists of their minds, brains, bodies, surrounding cultures etc.

A brand can't start its active life cycle without promotional activities like advertisements which carry the best attributes for the target groups. In a developing country like Bangladesh, the general perception is that advertising means television advertisement which is the most powerful paid form of non-personal audiovisual communication tool. Advertisements also help to upgrade consumer socialization process which consists of consumption-related cognition, attitudes, and values through different kinds of entertainment elements like music, information, action and popular celebrity endorsement (Abideen \& Saleem, 2011). It has been observed in different research findings of Bangladesh that the television advertisement is the best way to promote products and services in front of millions of consumers which also influences the buying behavior of consumers effectively and efficiently.

Dhaka, the capital of Bangladesh, which is one of the most populous cities in the world. People from each and every corner of the country flock to this city. Consequently, Dhaka has become the home of all the different classes of people who make up this country. Residents of this city have the luxury of watching almost all the major TV channels and networks of the world, especially Indian TV channels. This is also a major source of time passing and recreational facility for middle-class urban dwellers. So, research on the influence of TVCs and the buying decisions of the middle-class teenagers of Dhaka metro would be very appropriate and pertinent to meet the needs of the marketers, researchers, business academicians and entrepreneurs. That's why the research has planned to take teenagers of Dhaka city, aiming to know the influence of television and TV commercials on their buying decisions

\section{Research objectives}

The broad objective of the study is to investigate the influence of Television Commercials (TVCs) in the buying decision of the urban teenagers of Bangladesh. Specific objectives of the research are to explore a) TV and TVC watching pattern, b) reasons of watching TVC, c) popular TVCs, d) influence of TVCs on buying decision, e) information sharing the attitude, and f) influence of models on watching TVCs of the urban teenagers of Bangladesh.

\subsection{Literature review}

The first TVC of the world was aired on July 1, 1941, of a watch manufacturer named Bulova. Bangladesh Television (BTV), which was previously known as Pakistan Television (PTV - established on December 25, 1964) started its operation after the liberation of Bangladesh (December 16, 1971). Soon after its inception, BTV (erstwhile PTV) started airing TV commercials. Since then, TVCs have become an integral part of marketing communication to marketers for effective brand building. At present, it is one of to the biggest service industries across the globe for owners of TV stations and brand builders as well.

Extract of a pertinent literature review confirms that buying decision mostly depend on buying behavior (Consumer Behavior) of an individual. Where Consumer Behaviour may be defined as the study of individual customers, groups or organizations and how they select, buy, use, and dispose of ideas, goods, and services. Consumer buying behavior also refers to attitudes, preferences, and intentions of an individual while making a buying decision regarding a brand.

Lawan, L.A. and Zanna, R. (2013) mentioned two types of factors like internal factors and external factors that affect consumer buying decision. Internal factors are consumer's own judgment, test, preference, beliefs, lifestyle, personality, buying capacity etc. where external factors are society's culture such as norms, convention, customs, religion, festivity, class, lifestyle, entertainment vehicle, and another subculture influence etc.

According to Ramya, N and Ali, M.S.A., (2016), Buying behavior of consumer is affected by several factors or forces. These factors are broadly classified into four as Psychological Factors, Social Factors, 
Cultural Factors, Personal Factors, and Economic Factors. Such a decision-making process is classified into three types based on consumer involvement with the buying process which is nominal, limited and extended decision making. Extended decision making involves a higher level of buying involvement comparing to the other two types. These types of buying are infrequent and financial involvement is higher in such a case. That's why consumers go with the complex buying process.

It has been explored that the effect of advertising, particularly television advertising on youth is still one of the researchable topics worth studying (Abbas and Bari 2011, Anjum, Zamin and Bari 2015, Walter and Davie 1998). It is necessary to examine the positive or negative impact of television advertising on the socialization process and consumer buying behavior. Therefore various criticisms regarding the role of advertising in our society have emerged. On the contrary, most of the researchers have given their positive consensus regarding advertising; especially television advertising and its impact based on their research work. Many researchers are skeptic whether TVCs have a positive impact on teenagers' religiosity aspects.

As per the study of Barve, G., Sood, A., Nithya, S. \&Virmani, T (2015); media advertising, has never played a more crucial role in a teenager's socio-economic development and well-being. They also mentioned that children lack the experience and knowledge to understand and critically evaluate the purpose of the persuasive advertising appeals. For this reason, children are especially vulnerable to advertising. They also feel that pre-school children cannot differentiate between commercials and programs and cannot distinguish between reality and fantasy. Nonetheless, the importance of advertising cannot be deemphasized in the dynamic nature of our society. It has emerged as the most powerful tools in influencing socio-economic relations existing today.

Barve, G., Sood, A., Nithya, S. \&Virmani, T (2015) also explained that there is an extensive impact on the undeveloped brains of the kids and teens because of advertising. That is why the marketers have started targeting teens as a special segment for advertising. One of the reasons could be that teens or young people are impulsive buyers and do not think much before making the purchase decision. Another reason could be that the decision making the power of the children increasing day by day as they are influencing the family members more and more. Marketers consider this as an opportunity for paying special attention to target this segment, as advertisements normally have a mental and physical impact on teenagers' viewing of television.

Adiko, A. E. \&Adjei, D (2016) mentioned in their research finding that television advertisements by and large use persuasive techniques to appeal to consumers' sense of purchasing behaviors. Buying influence often depends on the kinds of advertisements. Most of the times, consumers turn down the contents of advertisements due to various reasons. Some believe that the information content has no diverse effect on their purchasing behaviors, while some believe that it has. They have added in their study that television advertising influences the young and pushes them to make purchase decisions. It has also come to light that the more they watch the advertisement, the higher the drive is to consume the product.

They have also concluded that most of the respondents watch television and, mostly enjoy watching television advertisements. It was also found that most of the respondents frequently viewed advertisements on television and make purchase decisions based on that. The outcome showed that loyalty to a product depends on the frequency of advertising. It was observed that the consumers' choice of product was related to exposure to the advertisement of the product. The results showed that television advertising is important in the marketing of a product, hence organizations who want to excel should do a lot of adverts.

Patel, G. \& Jain, R. (2015) stated that the advantage of television over the other mediums is the combination of audio and video features it exhibits. It also provides the products with instant validity and prominence and offers the greatest possibility for creative marketing. Over a longer period, the TV set has become a permanent fixture in all upper and middle-class households. Reactions to TV advertisements seem to be stronger than the reaction to print advertisements. The advertisers find it more effective to use television rather than print media to reach consumer' hearts and minds. TV advertising has been found not only to change emotions but also to influence the daily lives of people. 
They have found in their research that a young age group of 18-21 years in India is a regular viewer of television. They spend most of their free time watching television, following programs and channels of their choice. Most of the young generation believes television advertisements are informative and respond favorably. Marketers, use young people's power to influence the family purchase, choose TV commercials or programs to reach children or teenage youth together with their parents. They also added that teenagers are a strong influencing group having the ability to influence the purchase decisions in the family from cakes to cars.

Patel, G. \& Jain, R. (2015) concluded based on their research results that youths prefer TV advertisements and often want products seen in TV ads. They feel good when they watch the ads of the products that they are already using. TV ads help them to ensure the best products. The frequency of purchase increases due to TV advertisements. They prefer to buy and experiment with new products. Youth collectively decide with their family members, products to be purchased due to exposure to TV advertisements. It was also found that youngsters have a positive attitude toward TV commercials.

According to Rani, N, \& Sharma, V. (2014), television is still the most effective medium for reaching target customers and it is also the most efficient form for introducing new brands. TVCs allow marketers to show and tell a wide audience about business, products, or services. Television appeals to both literate and illiterate and this is one feature of TV that makes it unique and different from other mediums.

After all that is said and done, for brand building and promotion, the advertisement is second to none. Among all the different forms of advertisement, currently of digital media, television advertisement remains as the best medium, especially in the context of Bangladesh and its middle-class society. From an early age, children are exposed to television and they are accustomed to watching television commercials daily. Children, while watching TVCs subconsciously start thinking about the products in advertisements and slowly try to influence their parents to buy those products. Children are heavily influenced by TVCs as they step into teenage life. Though teenagers are more aware of their conscious minds and what to buy, they spend less time watching television and/or television commercials than children. In order to stay updated with the world and to stand out among their peers, teenagers are more open to try new products. So, naturally, their buying behavior is shaped and influenced greatly by an enticing TVC. Therefore, the correlation of watching TVC and the buying decision of middle-class teenagers of Dhaka are explored by this study with a suitable research methodology and analytical tools.

\subsection{Research methodology}

This research made use of both quantitative and qualitative methods of obtaining the required research information. A rigorous literature review has been conducted covering consumer buying behavior, TV and TVC watching pattern as well as its influence on teenagers' buying decision. These have given a clear indication to the researchers for developing a refined research methodology to conduct the research. This research has been conducted in Dhaka City, the capital of Bangladesh covering mainly the teen students (13-19 years) of middle income (Tk. 10k-100K per month) families.

The primary data is collected through a structured questionnaire. The questionnaire had two parts: part one consists of demographic variable of the respondents such as age, gender, income as well as education of the family and respondents as well. Part two consists of questions related to the influence and watching the pattern of TV and TVC resulting in buying decision. The relevant factors are explored through pertinent literature review, expert in-depth interview and two focus group discussions with teenage students. For sample size determination, the following formula is used which is mostly used for similar types of research.

$$
\begin{gathered}
\mathrm{N}=\frac{\mathrm{Nz} \mathrm{z}^{2} \mathrm{pq}}{\mathrm{z}^{2} \mathrm{pq}+\mathrm{d}^{2} \mathrm{~N}} \\
\text { When } \mathrm{N}=\text { Total number of teen students in Dhaka city }=573,599 \\
\mathrm{z}=1.96 \text { at } 5 \% \text { level of significance } \\
\mathrm{p}=0.5 \text { and } \mathrm{q}=0.5(\mathrm{pq}=0.25), \text { for result in maximum sample size. } \\
\mathrm{d}_{0}=0.05
\end{gathered}
$$




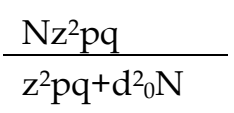

$573,599 \times 1.96^{2} \times(0.5 \times 0.5)$

$1.96^{2} \times(0.5 \times 0.5)+0.05^{2} 573,599$

$=383.9028863$

For convenience, we used 300 samples instead of 383.

A pre-testing or pilot testing has been conducted among 30 (10\% of total respondents) selective respondents from different demographic group to finalize the questionnaire. The final questionnaire survey received responses from 300 teenage students of different demographic groups over a period of 4 months by trained surveyors. A combination of non-probability convenience and purposive sampling technique has been used for data collection as no sample frame was available.

Secondary data has been retrieved from different published research papers of different international journals, statistical yearbooks, reports of some research companies, international and national NGO's.

Microsoft Excel and SPSS version 21 were used for the analysis of survey data which include frequency analysis, index analysis, dispersion, cross tabulation, t-test, Chi-square test etc.

\subsection{Research findings and analysis}

\subsection{TV watching habit}

The study observed that out of the 300 respondents, $70 \%$ watch TV regularly, 25\% occasionally and $5 \%$ never watches TV (Table 1). In terms of gender, it was noted that females were a little more inclined to watching TV (97\%) than their male counterparts (93\%). In terms of teen class, it was observed that the school going early teen respondents (13-16 years) watch TV regularly (84\%) or on occasion (16\%). For college or university going late teens (16-19 years), the chemistry is different: only $58 \%$ of them watch TV regularly, 32\% occasionally and 10\% never watches TV. This is further validated when looking into the classification of educational institution: school students watch more TV than college or university students. In terms of income group, it was observed that the lower-middle and middle-income group tends to watch TV more (97\% and 96\%) than the upper-middle income group (89\%).

\begin{tabular}{|c|c|c|c|c|c|c|c|c|c|c|c|}
\hline \multirow{2}{*}{$\begin{array}{l}\text { Demographic } \\
\text { Variables }\end{array}$} & \multirow[t]{2}{*}{ Categories } & \multicolumn{2}{|c|}{ Total } & \multicolumn{2}{|l|}{ Yes } & \multicolumn{2}{|c|}{ No } & \multicolumn{2}{|c|}{ Sometimes } & \multicolumn{2}{|c|}{$\begin{array}{l}\text { Yes+ } \\
\text { Sometimes }\end{array}$} \\
\hline & & $\mathrm{f}$ & $\%$ & $\mathrm{f}$ & $\%$ & $\mathrm{f}$ & $\%$ & $\mathrm{f}$ & $\%$ & $\mathrm{f}$ & $\%$ \\
\hline All & Total & 300 & $100 \%$ & 210 & $70 \%$ & 16 & $5 \%$ & 74 & $25 \%$ & 284 & $95 \%$ \\
\hline \multirow{2}{*}{ Gender } & Male & 164 & $55 \%$ & 113 & $69 \%$ & 12 & $7 \%$ & 39 & $24 \%$ & 152 & $93 \%$ \\
\hline & Female & 136 & $45 \%$ & 97 & $71 \%$ & 4 & $3 \%$ & 35 & $26 \%$ & 132 & $97 \%$ \\
\hline \multirow{2}{*}{ Teens Class } & Early teen & 137 & $46 \%$ & 115 & $84 \%$ & 0 & $0 \%$ & 22 & $16 \%$ & 137 & $100 \%$ \\
\hline & Late teen & 163 & $54 \%$ & 95 & $58 \%$ & 16 & $10 \%$ & 52 & $32 \%$ & 147 & $90 \%$ \\
\hline \multirow{3}{*}{ Income Group } & $\begin{array}{l}\text { Lower- } \\
\text { middle }\end{array}$ & 67 & $22 \%$ & 49 & $73 \%$ & 2 & $3 \%$ & 16 & $24 \%$ & 65 & $97 \%$ \\
\hline & Middle & 163 & $54 \%$ & 115 & $71 \%$ & 6 & $4 \%$ & 42 & $26 \%$ & 157 & $96 \%$ \\
\hline & $\begin{array}{l}\text { Upper- } \\
\text { middle }\end{array}$ & 70 & $23 \%$ & 46 & $66 \%$ & 8 & $11 \%$ & 16 & $23 \%$ & 62 & $89 \%$ \\
\hline \multirow{3}{*}{ Institution } & School & 123 & $41 \%$ & 104 & $85 \%$ & 0 & $0 \%$ & 19 & $15 \%$ & 123 & $100 \%$ \\
\hline & College & 80 & $27 \%$ & 54 & $68 \%$ & 3 & $4 \%$ & 23 & $29 \%$ & 77 & $96 \%$ \\
\hline & University & 97 & $32 \%$ & 52 & $54 \%$ & 13 & $13 \%$ & 32 & $33 \%$ & 84 & $87 \%$ \\
\hline
\end{tabular}

Table 1: TV Watching Habit

Note Early teen (13-16 years), Late teen (17-19 years), Lower middle income (10-35k), Middle income (36-70k), and Upper middle income (above 71k).

\subsection{Popular TV programs}


The common TV programs available are sports, drama serial, reality show, news, and talk shows. Of the total respondents, about $41 \%$ prefer to watch sports, $29 \%$ prefer drama serial, $21 \%$ prefer reality shows, $7 \%$ prefer news and only 3\% prefer talk shows (Table 2). The females were more inclined to watching drama serials $(57 \%)$ and reality shows $(26 \%)$ whereas the majority of the males prefer watching sports (67\%). Both teen groups prefer watching sports (Early teen $40 \%$ and late teen $42 \%$ ) more than anything else. A large portion of the early teens preferring to watch drama serials (36\%). Income wise all the three categories (lower middle, middle, upper middle) have given their best preference for sports $(45 \%, 39 \%, 41 \%)$. This was followed by drama serial $(30 \%, 33 \% 19 \%)$ and realty shows $(18 \%, 21 \%, 21 \%)$. Talk show and news are found to be least preferred TV programs for them.

The statistics for sports watching remains highest at all level for an educational institution (school $41 \%$, college $43 \%$, and university $40 \%$ ); however, the school students watch more drama serials (41\%) than the college $(21 \%)$ and university students $(20 \%)$.

\begin{tabular}{|c|c|c|c|c|c|c|c|c|c|c|c|c|c|}
\hline \multirow{2}{*}{$\begin{array}{l}\text { Demogr } \\
\text { aphic } \\
\text { Variabl } \\
\text { es }\end{array}$} & \multirow{2}{*}{ Categories } & \multicolumn{2}{|c|}{ Total } & \multicolumn{2}{|c|}{$\begin{array}{l}\text { Drama } \\
\text { Serial } \\
\end{array}$} & \multicolumn{2}{|c|}{ News } & \multicolumn{2}{|c|}{$\begin{array}{l}\text { Talk } \\
\text { Show }\end{array}$} & \multicolumn{2}{|c|}{$\begin{array}{l}\text { Reality } \\
\text { Show }\end{array}$} & \multicolumn{2}{|c|}{ Sports } \\
\hline & & $\mathrm{f}$ & $\%$ & $\mathrm{f}$ & $\%$ & $\mathrm{f}$ & $\%$ & $\mathrm{f}$ & $\%$ & $\mathrm{f}$ & $\%$ & $\mathrm{f}$ & $\%$ \\
\hline All & Total & 300 & $100 \%$ & 86 & $29 \%$ & 20 & $7 \%$ & 9 & $3 \%$ & 62 & $21 \%$ & 123 & $41 \%$ \\
\hline \multirow{2}{*}{ Gender } & Male & 164 & $55 \%$ & 9 & $5 \%$ & 13 & $8 \%$ & 6 & $4 \%$ & 26 & $16 \%$ & 110 & $67 \%$ \\
\hline & Female & 136 & $45 \%$ & 77 & $57 \%$ & 7 & $5 \%$ & 3 & $2 \%$ & 36 & $26 \%$ & 13 & $10 \%$ \\
\hline \multirow{2}{*}{$\begin{array}{l}\text { Teens } \\
\text { Class }\end{array}$} & Early Teen & 137 & $46 \%$ & 49 & $36 \%$ & 3 & $2 \%$ & 2 & $1 \%$ & 28 & $20 \%$ & 55 & $40 \%$ \\
\hline & Late Teen & 163 & $54 \%$ & 37 & $23 \%$ & 17 & $10 \%$ & 7 & $4 \%$ & 34 & $21 \%$ & 68 & $42 \%$ \\
\hline \multirow{3}{*}{$\begin{array}{l}\text { Income } \\
\text { Group }\end{array}$} & Lower-Middle & 67 & $22 \%$ & 20 & $30 \%$ & 4 & $6 \%$ & 1 & $1 \%$ & 12 & $18 \%$ & 30 & $45 \%$ \\
\hline & Middle & 163 & $54 \%$ & 53 & $33 \%$ & 9 & $6 \%$ & 2 & $1 \%$ & 35 & $21 \%$ & 64 & $39 \%$ \\
\hline & Upper-Middle & 70 & $23 \%$ & 13 & $19 \%$ & 7 & $10 \%$ & 6 & $9 \%$ & 15 & $21 \%$ & 29 & $41 \%$ \\
\hline \multirow{3}{*}{$\begin{array}{l}\text { Instituti } \\
\text { on }\end{array}$} & School & 123 & $41 \%$ & 50 & $41 \%$ & 1 & $1 \%$ & 1 & $1 \%$ & 21 & $17 \%$ & 50 & $41 \%$ \\
\hline & College & 80 & $27 \%$ & 17 & $21 \%$ & 10 & $13 \%$ & 3 & $4 \%$ & 16 & $20 \%$ & 34 & $43 \%$ \\
\hline & University & 97 & $32 \%$ & 19 & $20 \%$ & 9 & $9 \%$ & 5 & $5 \%$ & 25 & $26 \%$ & 39 & $40 \%$ \\
\hline
\end{tabular}

Table 2: Popular TV Program

\subsection{Peak hour of TV watching}

TV watching time has been classified as the morning (midnight to $12 \mathrm{pm}$ ), afternoon (12 pm to 6 $\mathrm{pm})$, evening ( $6 \mathrm{pm}$ to $9 \mathrm{pm}$ ) and night (9 pm to midnight). This was done to find out the peak, semi-peak and off-peak watching hours. The study noted that $71 \%$ of the respondents watch TV at night, $21 \%$ watch in the evening, $5 \%$ in the afternoon, and only $4 \%$ in the morning (Table 3 ). Hence it is very clear that for the urban youths, nighttime can be defined as peak hour and evening as a semi-peak hour. Whereas afternoon, as well as morning, can be treated as an off-peak hour. It is more or less applicable across all the classifications.

\begin{tabular}{|c|c|c|c|c|c|c|c|c|c|c|c|c|c|}
\hline \multirow{2}{*}{$\begin{array}{l}\text { Demographic } \\
\text { Variables }\end{array}$} & \multirow[t]{2}{*}{ Categories } & \multicolumn{2}{|c|}{ Total } & \multicolumn{2}{|c|}{ Morning } & \multicolumn{2}{|c|}{ Afternoon } & \multicolumn{2}{|c|}{ Evening } & \multicolumn{2}{|c|}{ Night } & \multicolumn{2}{|c|}{$\begin{array}{l}\text { Evening+ } \\
\text { Night }\end{array}$} \\
\hline & & $\mathrm{f}$ & $\%$ & $\mathrm{f}$ & $\%$ & $\mathrm{~F}$ & $\%$ & $\mathrm{f}$ & $\%$ & $\mathrm{f}$ & $\%$ & $f$ & $\%$ \\
\hline All & Total & 300 & $100 \%$ & 11 & $4 \%$ & 14 & $5 \%$ & 62 & $21 \%$ & 213 & $71 \%$ & 275 & $92 \%$ \\
\hline \multirow{2}{*}{ Gender } & Male & 164 & $55 \%$ & 7 & $4 \%$ & 9 & $5 \%$ & 28 & $17 \%$ & 120 & $73 \%$ & 148 & $90 \%$ \\
\hline & Female & 136 & $45 \%$ & 4 & $3 \%$ & 5 & $4 \%$ & 34 & $25 \%$ & 93 & $68 \%$ & 127 & $93 \%$ \\
\hline \multirow{2}{*}{ Teens Class } & Early Teen & 137 & $46 \%$ & 10 & $7 \%$ & 2 & $1 \%$ & 27 & $20 \%$ & 98 & $72 \%$ & 125 & $91 \%$ \\
\hline & Late Teen & 163 & $54 \%$ & 1 & $1 \%$ & 12 & $7 \%$ & 35 & $21 \%$ & 115 & $71 \%$ & 150 & $92 \%$ \\
\hline \multirow{3}{*}{$\begin{array}{l}\text { Income } \\
\text { Group }\end{array}$} & $\begin{array}{l}\text { Lower- } \\
\text { Middle }\end{array}$ & 67 & $22 \%$ & 3 & $4 \%$ & 5 & $7 \%$ & 17 & $25 \%$ & 42 & $63 \%$ & 59 & $88 \%$ \\
\hline & Middle & 163 & $54 \%$ & 7 & $4 \%$ & 3 & $2 \%$ & 32 & $20 \%$ & 121 & $74 \%$ & 153 & $94 \%$ \\
\hline & $\begin{array}{l}\text { Upper- } \\
\text { Middle } \\
\end{array}$ & 70 & $23 \%$ & 1 & $1 \%$ & 6 & $9 \%$ & 13 & $19 \%$ & 50 & $71 \%$ & 63 & $90 \%$ \\
\hline \multirow{2}{*}{ Institution } & School & 123 & $41 \%$ & 9 & $7 \%$ & 2 & $2 \%$ & 25 & $20 \%$ & 87 & $71 \%$ & 112 & $91 \%$ \\
\hline & College & 80 & $27 \%$ & 1 & $1 \%$ & 6 & $8 \%$ & 15 & $19 \%$ & 58 & $73 \%$ & 73 & $91 \%$ \\
\hline
\end{tabular}




\begin{tabular}{|l|l|l|l|l|l|l|l|l|l|l|l|l|}
\hline University & 97 & $32 \%$ & 1 & $1 \%$ & 6 & $6 \%$ & 22 & $23 \%$ & 68 & $70 \%$ & 90 & $93 \%$ \\
\hline
\end{tabular}

Table 3: Peak Hour of TV Watching

Note: Morning: 12am-12pm, Afternoon: 12pm-6pm, Evening: 6pm-9pm, Night: 9pm-12pm.

\subsection{TVC watching pattern}

Regarding TVC watching pattern the study revealed that out of the 300 respondents $53 \%$ watch TVC regularly, $36 \%$ occasionally and $11 \%$ never watches TVC (Table 4$)$. Gender wise females were $(90 \%)$ found to watch TVC a little more than males (88\%). The early teen respondents watch TVC more $(94 \%)$ than the late teen respondents $(85 \%)$. It was also explored that the school students watch TVC (95\%) more than the college $(88 \%)$ and university students $(83 \%)$. This research finding also ratifies the research observation of Waqas, Aslam, Bilai, and Umair (2014) where they stated that the age of children is the most influential factor in buying advertised products. (E.g. higher the age, more the advertised products purchased). On the other hand, the lower-middle and middle-income group tends to watch TVC more $(91 \%)$ than the upper-middle income group $(83 \%)$. It is worth noting that the TVC watching pattern almost coincides with the TV watching patterns.

\begin{tabular}{|c|c|c|c|c|c|c|c|c|c|c|c|}
\hline \multirow{2}{*}{$\begin{array}{l}\text { Demographic } \\
\text { Variables }\end{array}$} & \multirow{2}{*}{ Categories } & \multicolumn{2}{|c|}{ Total } & \multicolumn{2}{|c|}{ Regularly } & \multicolumn{2}{|c|}{ Not watch } & \multicolumn{2}{|c|}{ Sometimes } & \multicolumn{2}{|c|}{$\begin{array}{l}\text { Regularly } \\
\text { Sometimes }\end{array}$} \\
\hline & & $f$ & $\%$ & $\mathrm{f}$ & $\%$ & $\mathrm{f}$ & $\%$ & $\mathrm{f}$ & $\%$ & $\mathrm{f}$ & $\%$ \\
\hline All & Total & 300 & $100 \%$ & 159 & $53 \%$ & 33 & $11 \%$ & 108 & $36 \%$ & 267 & $89 \%$ \\
\hline \multirow{2}{*}{ Gender } & Male & 164 & $55 \%$ & 80 & $49 \%$ & 20 & $12 \%$ & 64 & $39 \%$ & 144 & $88 \%$ \\
\hline & Female & 136 & $45 \%$ & 79 & $58 \%$ & 13 & $10 \%$ & 44 & $32 \%$ & 123 & $90 \%$ \\
\hline \multirow{2}{*}{ Teens Class } & Early Teen & 137 & $46 \%$ & 80 & $58 \%$ & 8 & $6 \%$ & 49 & $36 \%$ & 129 & $94 \%$ \\
\hline & Late Teen & 163 & $54 \%$ & 79 & $48 \%$ & 25 & $15 \%$ & 59 & $36 \%$ & 138 & $85 \%$ \\
\hline \multirow{3}{*}{$\begin{array}{l}\text { Income } \\
\text { Group }\end{array}$} & $\begin{array}{l}\text { Lower- } \\
\text { Middle }\end{array}$ & 67 & $22 \%$ & 32 & $48 \%$ & 6 & $9 \%$ & 29 & $43 \%$ & 61 & $91 \%$ \\
\hline & Middle & 163 & $54 \%$ & 92 & $56 \%$ & 15 & $9 \%$ & 56 & $34 \%$ & 148 & $91 \%$ \\
\hline & $\begin{array}{l}\text { Upper- } \\
\text { Middle }\end{array}$ & 70 & $23 \%$ & 35 & $50 \%$ & 12 & $17 \%$ & 23 & $33 \%$ & 58 & $83 \%$ \\
\hline \multirow{3}{*}{ Institution } & School & 123 & $41 \%$ & 71 & $58 \%$ & 6 & $5 \%$ & 46 & $37 \%$ & 117 & $95 \%$ \\
\hline & College & 80 & $27 \%$ & 45 & $56 \%$ & 10 & $13 \%$ & 25 & $31 \%$ & 70 & $88 \%$ \\
\hline & University & 97 & $32 \%$ & 43 & $44 \%$ & 17 & $18 \%$ & 37 & $38 \%$ & 80 & $82 \%$ \\
\hline
\end{tabular}

Table 4: TVC Watching Pattern

\subsection{TVC watching reason}

Two major reasons for watching TVC have been noticed in the research: i) TVCs have become a part of the TV programs that respondents prefer more ii) The TVCs is itself enjoyable. The study noted that the majority $(52 \%)$ of the respondents watch the TVC as a part of a TV program (Table 5) while a substantial number $(39 \%)$ loves to watch TVC for its entertainment values. Only a small (4\%) number of respondents watch TVC influenced by others. As per different demographic characteristics (Gender, a teen class, income, institution), a similar response pattern is observed in the study. Among all the demographic groups, college students $(66 \%)$ seem to watch TVCs mainly because these are embedded in popular TV programs, but they are found to enjoy TVCs comparatively less (21\%) than the TV program.

\begin{tabular}{|l|l|l|l|l|l|l|l|l|l|l|l|}
\hline \multirow{2}{*}{$\begin{array}{l}\text { Demographic } \\
\text { Variables }\end{array}$} & \multirow{2}{*}{ Categories } & \multicolumn{2}{|l|}{ Total } & \multicolumn{2}{l}{$\begin{array}{l}\text { Part of a TV } \\
\text { program }\end{array}$} & \multicolumn{2}{l|}{ Enjoy myself } & \multicolumn{2}{l|}{$\begin{array}{l}\text { Influence of } \\
\text { others }\end{array}$} & \multicolumn{2}{l|}{ Others } \\
\cline { 3 - 13 } & & $\mathrm{f}$ & $\%$ & $\mathrm{~F}$ & $\%$ & $\mathrm{~F}$ & $\%$ & $\mathrm{f}$ & $\%$ & $\mathrm{f}$ & $\%$ \\
\hline \multirow{2}{*}{ All } & Total & 300 & $100 \%$ & 156 & $52 \%$ & 116 & $39 \%$ & 12 & $4 \%$ & 16 & $5 \%$ \\
\hline \multirow{3}{*}{ Teender } & Male & 164 & $55 \%$ & 84 & $51 \%$ & 66 & $40 \%$ & 9 & $5 \%$ & 5 & $3 \%$ \\
\cline { 2 - 14 } & Female & 136 & $45 \%$ & 72 & $53 \%$ & 50 & $37 \%$ & 3 & $2 \%$ & 11 & $8 \%$ \\
\hline
\end{tabular}

www.jbrmr.com A Journal of the Academy of Business and Retail Management (ABRM) 


\begin{tabular}{|l|l|l|l|l|l|l|l|l|l|l|l|}
\hline \multirow{5}{*}{ Income Group } & $\begin{array}{l}\text { Lower- } \\
\text { Middle }\end{array}$ & 67 & $22 \%$ & 31 & $46 \%$ & 30 & $45 \%$ & 2 & $3 \%$ & 4 & $6 \%$ \\
\cline { 2 - 12 } & Middle & 163 & $54 \%$ & 90 & $55 \%$ & 59 & $36 \%$ & 5 & $3 \%$ & 9 & $6 \%$ \\
\cline { 2 - 12 } & $\begin{array}{l}\text { Upper- } \\
\text { Middle }\end{array}$ & 70 & $23 \%$ & 35 & $50 \%$ & 27 & $39 \%$ & 5 & $7 \%$ & 3 & $4 \%$ \\
\hline \multirow{5}{*}{ Institution } & School & 123 & $41 \%$ & 62 & $50 \%$ & 58 & $47 \%$ & 1 & $1 \%$ & 2 & $2 \%$ \\
\cline { 2 - 12 } & College & 80 & $27 \%$ & 53 & $66 \%$ & 17 & $21 \%$ & 0 & $0 \%$ & 10 & $13 \%$ \\
\cline { 2 - 12 } & University & 97 & $32 \%$ & 41 & $42 \%$ & 41 & $42 \%$ & 11 & $11 \%$ & 4 & $4 \%$ \\
\hline
\end{tabular}

Table 5: TVC Watching Reason

\subsection{Popular type of TVC}

The study identified the popular types of TVCs noted by urban teens. The respondents were given the option to choose from three types of TVCs: i) funny ${ }^{2}$, ii) informative ${ }^{3}$, and iii) thematic ${ }^{4}$. The study noted that the respondents like the funny $(37 \%)$ and informative $(33 \%)$ commercials more than the thematic ones (15\%) (Table 6). Outcomes from research finding of Farooq, Shafique, Khurshid and Ahmad (2015) also revealed that comedy in TVC has the highest influence to convince the young student's attention, interest, desire and action (AIDA) to buy the product. About $15 \%$ mentioned that they are indifferent of any specific type of TVC. The females found to like the funny (40\%) TVCs more than the males (35\%); whereas, the males like the informative TVCs $(40 \%)$ more than the females $(33 \%)$. Overall more males $(40 \%)$ like informative TVC. While more females $(40 \%)$ like funny TVC. The study further noted that early teens prefer both funny and informative TVCs $(40 \%$ and $39 \%)$ more than the late teens $(34 \%$ and $29 \%)$. A significant portion of late teens (25\%) are found to prefer all three types of TVCs.

Income wise, the middle class (44\%) are found to prefer funny TVCs the most. On the other hand, the majority of lower-middle $(37 \%)$ and upper-middle (34\%) income groups prefer informative TVCs. Furthermore, the middle income $(37 \%)$ are found to prefer informative TVCs the most. This is followed by upper-middle (34\%) and middle (31\%) income groups. Education wise school children $(41 \%)$ are found to love the funny TVCs most and then informative (36\%) and thematic (21\%) TVCs. Similar pattern is observed for college students (Funny: 38\%, Informative: 30\%, Thematic: 14\%). The university students are found to prefer almost equally informative (33\%) and funny (32\%) TVCs. But a significant portion (28\%) are found to prefer all the three types of TVCs.

Virvilaite \& Matuleviciene (2013) have identified the impact of shocking advertising in their research paper which is not included in the research work. According to the research outcome, younger consumers have a more positive view of shocking advertising than older consumers. Also, women have a more negative view of shocking advertising than men. A positive view of shocking advertising causes positive buying behavior. On the contrary, a negative view of shocking advertising does not always cause negative buying behavior.

\begin{tabular}{|c|c|c|c|c|c|c|c|c|c|c|c|}
\hline \multirow{2}{*}{$\begin{array}{l}\text { Demographic } \\
\text { Variables }\end{array}$} & \multirow{2}{*}{ Categories } & \multicolumn{2}{|c|}{ Total } & \multicolumn{2}{|c|}{ Funny } & \multicolumn{2}{|c|}{ Thematic } & \multicolumn{2}{|c|}{ Informative } & \multicolumn{2}{|c|}{ All types } \\
\hline & & $\mathrm{F}$ & $\%$ & $\mathrm{f}$ & $\%$ & $\mathrm{f}$ & $\%$ & f & $\%$ & $f$ & $\%$ \\
\hline All & Total & 300 & $100 \%$ & 111 & $37 \%$ & 44 & $15 \%$ & 100 & $33 \%$ & 45 & $15 \%$ \\
\hline \multirow{2}{*}{ Gender } & Male & 164 & $55 \%$ & 57 & $35 \%$ & 18 & $11 \%$ & 66 & $40 \%$ & 23 & $14 \%$ \\
\hline & Female & 136 & $45 \%$ & 54 & $40 \%$ & 26 & $19 \%$ & 34 & $25 \%$ & 22 & $16 \%$ \\
\hline \multirow{2}{*}{ Teens Class } & Early Teen & 137 & $46 \%$ & 55 & $40 \%$ & 25 & $18 \%$ & 53 & $39 \%$ & 4 & $3 \%$ \\
\hline & Late Teen & 163 & $54 \%$ & 56 & $34 \%$ & 19 & $12 \%$ & 47 & $29 \%$ & 41 & $25 \%$ \\
\hline \multirow{3}{*}{ Income Group } & Lower-Middle & 67 & $22 \%$ & 18 & $27 \%$ & 14 & $21 \%$ & 25 & $37 \%$ & 10 & $15 \%$ \\
\hline & Middle & 163 & $54 \%$ & 72 & $44 \%$ & 22 & $13 \%$ & 51 & $31 \%$ & 18 & $11 \%$ \\
\hline & Upper-Middle & 70 & $23 \%$ & 21 & $30 \%$ & 8 & $11 \%$ & 24 & $34 \%$ & 17 & $24 \%$ \\
\hline \multirow{2}{*}{ Institution } & School & 123 & $41 \%$ & 50 & $41 \%$ & 26 & $21 \%$ & 44 & $36 \%$ & 3 & $2 \%$ \\
\hline & College & 80 & $27 \%$ & 30 & $38 \%$ & 11 & $14 \%$ & 24 & $30 \%$ & 15 & $19 \%$ \\
\hline
\end{tabular}

www.jbrmr.com A Journal of the Academy of Business and Retail Management (ABRM) 


\begin{tabular}{|l|l|l|l|l|l|l|l|l|l|l|l|}
\hline & University & 97 & $32 \%$ & 31 & $32 \%$ & 7 & $7 \%$ & 32 & $33 \%$ & 27 & $28 \%$ \\
\hline
\end{tabular}

Table 6: Popular Type of TVC

\subsection{Influence of TVC on buying decision}

Considering the influence of TVC on buying decision, out of the 300 respondents $37 \%$ responded positively, 30\% occasionally and 33\% negatively (Table 7). This indicates a significant influence of TVCs on purchase decisions. Gender wise, the females (regularly $42 \%+$ occasionally $27 \%$ ) were more influenced by TVCs to take purchase decision than males (regularly34\%+occasionally $32 \%$ ). The late teens were more influenced by TVCs $(71 \%)$ than the early teens $(62 \%)$. It is further explored that school students were more influenced by TVC $(50 \%)$ than the college $(28 \%)$ or university students $(30 \%)$. Moreover, the upper-middle income group tends to be more influenced by TVCs $(79 \%)$ than the lower and middle-income group $(63 \%$ and $64 \%$ ) respectively. Hence, it can be concluded that there is a strong influence of TVCs on buying decision of urban teens, irrespective of demographic features.

\begin{tabular}{|c|c|c|c|c|c|c|c|c|c|c|c|}
\hline \multirow{2}{*}{$\begin{array}{l}\text { Demographic } \\
\text { Variables }\end{array}$} & \multirow{2}{*}{ Categories } & \multicolumn{2}{|c|}{ Total } & \multicolumn{2}{|l|}{ Yes } & \multicolumn{2}{|c|}{ No } & \multicolumn{2}{|c|}{ Sometimes } & \multicolumn{2}{|c|}{$\begin{array}{l}\text { Yes+ } \\
\text { Sometimes }\end{array}$} \\
\hline & & $\mathrm{f}$ & $\%$ & $\mathrm{f}$ & $\%$ & $\mathrm{f}$ & $\%$ & $\mathrm{f}$ & $\%$ & $\mathrm{f}$ & $\%$ \\
\hline All & Total & 300 & $100 \%$ & 112 & $37 \%$ & 99 & $33 \%$ & 89 & $30 \%$ & 201 & $67 \%$ \\
\hline \multirow{2}{*}{ Gender } & Male & 164 & $55 \%$ & 55 & $34 \%$ & 57 & $35 \%$ & 52 & $32 \%$ & 107 & $65 \%$ \\
\hline & Female & 136 & $45 \%$ & 57 & $42 \%$ & 42 & $31 \%$ & 37 & $27 \%$ & 94 & $69 \%$ \\
\hline \multirow{2}{*}{ Teens Class } & Early Teen & 137 & $46 \%$ & 64 & $47 \%$ & 52 & $38 \%$ & 21 & $15 \%$ & 85 & $62 \%$ \\
\hline & Late Teen & 163 & $54 \%$ & 48 & $29 \%$ & 47 & $29 \%$ & 68 & $42 \%$ & 116 & $71 \%$ \\
\hline \multirow{3}{*}{ Income Group } & $\begin{array}{l}\text { Lower- } \\
\text { Middle }\end{array}$ & 67 & $22 \%$ & 24 & $36 \%$ & 25 & $37 \%$ & 18 & $27 \%$ & 42 & $63 \%$ \\
\hline & Middle & 163 & $54 \%$ & 61 & $37 \%$ & 59 & $36 \%$ & 43 & $26 \%$ & 104 & $64 \%$ \\
\hline & $\begin{array}{l}\text { Upper- } \\
\text { Middle }\end{array}$ & 70 & $23 \%$ & 27 & $39 \%$ & 15 & $21 \%$ & 28 & $40 \%$ & 55 & $79 \%$ \\
\hline \multirow{3}{*}{ Institution } & School & 123 & $41 \%$ & 61 & $50 \%$ & 47 & $38 \%$ & 15 & $12 \%$ & 76 & $62 \%$ \\
\hline & College & 80 & $27 \%$ & 22 & $28 \%$ & 29 & $36 \%$ & 29 & $36 \%$ & 51 & $64 \%$ \\
\hline & University & 97 & $32 \%$ & 29 & $30 \%$ & 23 & $24 \%$ & 45 & $46 \%$ & 74 & $76 \%$ \\
\hline
\end{tabular}

Table 7: Influence of TVC on Buying Decision

\subsection{Product purchasing by TVC watching}

In terms of final purchase, the study explored that a good number of respondents (35\%) frequently and infrequently (15\%) buy products watching TVCs (Table 8). But the majority (53\%) mentioned that they do not make any direct purchase influenced by TVCs. Hence, there is evidence of the difference between desire and action ${ }^{5}$. It has been noticed in the research result of Rehman, Newaz, Khan and Hyder (2014) that rural teens are also highly influenced by advertisement through the AIDA model. Its implication is also found in frequent purchase decision making. So, it can be concluded that both rural and urban teens are equally inclined by TVC regarding purchase decision. However, Vani, Babu, and Panchanatham (2011) have given highest importance on awareness level of teenagers which dominates their decision for selecting a product and a brand. Gender wise, the females $(38 \%+16 \%)$ are more influenced by TVCs to purchase than males $(28 \%+13 \%)$. The late teens are more influenced by TVC $(64 \%)$ than the early teens $(28 \%)$. It is further affirmed by the responses that college $(51 \%)$ and university students $(71 \%)$ are more influenced by TVCs to purchase than the school students $(26 \%)$. Furthermore, the upper-middle income group purchases more by the influence of TVCs $(66 \%)$ than the lower and middleincome group (39\% and $43 \%$ ) respectively. Therefore, it can be concluded that regardless of demographic features there is a significant influence of TVCs to purchase products. 


\begin{tabular}{|c|c|c|c|c|c|c|c|c|c|c|c|}
\hline \multirow{2}{*}{$\begin{array}{l}\text { Demographic } \\
\text { Variables }\end{array}$} & \multirow{2}{*}{ Categories } & \multicolumn{2}{|c|}{ Total } & \multicolumn{2}{|c|}{ Yes } & \multicolumn{2}{|l|}{ No } & \multicolumn{2}{|c|}{ Sometimes } & \multicolumn{2}{|c|}{$\begin{array}{l}\text { Yes+ } \\
\text { Sometimes }\end{array}$} \\
\hline & & $\mathrm{F}$ & $\%$ & $\mathrm{f}$ & $\%$ & $\mathrm{f}$ & $\%$ & $\mathrm{f}$ & $\%$ & $\mathrm{f}$ & $\%$ \\
\hline All & Total & 300 & $100 \%$ & 98 & $33 \%$ & 158 & $53 \%$ & 44 & $15 \%$ & 142 & $47 \%$ \\
\hline \multirow{2}{*}{ Gender } & Male & 164 & $55 \%$ & 46 & $28 \%$ & 96 & $59 \%$ & 22 & $13 \%$ & 68 & $41 \%$ \\
\hline & Female & 136 & $45 \%$ & 52 & $38 \%$ & 62 & $46 \%$ & 22 & $16 \%$ & 74 & $54 \%$ \\
\hline \multirow{2}{*}{ Teens Class } & Early Teen & 137 & $46 \%$ & 31 & $23 \%$ & 99 & $72 \%$ & 7 & $5 \%$ & 38 & $28 \%$ \\
\hline & Late Teen & 163 & $54 \%$ & 67 & $41 \%$ & 59 & $36 \%$ & 37 & $23 \%$ & 104 & $64 \%$ \\
\hline \multirow{3}{*}{$\begin{array}{l}\text { Income } \\
\text { Group }\end{array}$} & Lower-Middle & 67 & $22 \%$ & 17 & $25 \%$ & 41 & $61 \%$ & 9 & $13 \%$ & 26 & $39 \%$ \\
\hline & Middle & 163 & $54 \%$ & 50 & $31 \%$ & 93 & $57 \%$ & 20 & $12 \%$ & 70 & $43 \%$ \\
\hline & Upper-Middle & 70 & $23 \%$ & 31 & $44 \%$ & 24 & $34 \%$ & 15 & $21 \%$ & 46 & $66 \%$ \\
\hline \multirow{3}{*}{ Institution } & School & 123 & $41 \%$ & 26 & $21 \%$ & 91 & $74 \%$ & 6 & $5 \%$ & 32 & $26 \%$ \\
\hline & College & 80 & $27 \%$ & 29 & $36 \%$ & 39 & $49 \%$ & 12 & $15 \%$ & 41 & $51 \%$ \\
\hline & University & 97 & $32 \%$ & 43 & $44 \%$ & 28 & $29 \%$ & 26 & $27 \%$ & 69 & $71 \%$ \\
\hline
\end{tabular}

Table 8: Product Purchasing by TVC Watching

\subsection{Influence of models on TVC watching}

The study regarded that the majority $(65 \%)$ of the respondents were influenced by models or celebrities to watch the TVC (Table 9). Demographic variables (gender, a teen class, income group, and institution) and similar trends are observed in the study. In addition, not much difference is observed within each of these demographic groups. However, this percentage is a little higher for the females $(66 \%)$, early teens $(69 \%)$, upper-middle income group $(73 \%)$, and school going children $(70 \%)$. Hence, we can state that there is an influence of models/celebrities among urban teens in watching TVCs.

\begin{tabular}{|l|l|l|l|l|l|l|l|}
\hline \multirow{2}{*}{$\begin{array}{l}\text { Demographic } \\
\text { Variables }\end{array}$} & \multirow{2}{*}{ Categories } & \multicolumn{2}{l}{ Total } & \multicolumn{2}{l|}{ Yes } & \multicolumn{2}{l|}{ No } \\
\cline { 3 - 8 } & & $\mathrm{f}$ & $\%$ & $\mathrm{f}$ & $\%$ & $\mathrm{f}$ & $\%$ \\
\hline All & Total & 300 & $100 \%$ & 195 & $65 \%$ & 105 & $35 \%$ \\
\hline \multirow{2}{*}{ Gender } & Male & 164 & $55 \%$ & 105 & $64 \%$ & 59 & $36 \%$ \\
\cline { 2 - 8 } & Female & 136 & $45 \%$ & 90 & $66 \%$ & 46 & $34 \%$ \\
\hline \multirow{2}{*}{ Teens Class } & Early Teen & 137 & $46 \%$ & 94 & $69 \%$ & 43 & $31 \%$ \\
\cline { 2 - 8 } & Late Teen & 163 & $54 \%$ & 101 & $62 \%$ & 62 & $38 \%$ \\
\hline \multirow{3}{*}{ Income Group } & Lower-Middle & 67 & $22 \%$ & 40 & $60 \%$ & 27 & $40 \%$ \\
\cline { 2 - 8 } & Middle & 163 & $54 \%$ & 104 & $64 \%$ & 59 & $36 \%$ \\
\cline { 2 - 8 } & Upper-Middle & 70 & $23 \%$ & 51 & $73 \%$ & 19 & $27 \%$ \\
\hline \multirow{3}{*}{ Institution } & School & 123 & $41 \%$ & 86 & $70 \%$ & 37 & $30 \%$ \\
\cline { 2 - 8 } & College & 80 & $27 \%$ & 49 & $61 \%$ & 31 & $39 \%$ \\
\cline { 2 - 8 } & University & 97 & $32 \%$ & 60 & $62 \%$ & 37 & $38 \%$ \\
\hline
\end{tabular}

Table 9: Influence of Models on TVC Watching

\subsection{TVC information sharing attitude}

It has been revealed by the research that a large portion of the respondents frequently $(55 \%)$ and infrequently $(28 \%)$ share TVC information with others while very few $(17 \%)$ has no sharing attitude (Table 10). Demographic variable wise (gender, a teen class, income group, and institution) similar trend is observed in the study. Sharing attitude was more prominent among females (frequent $58 \%$, infrequent $28 \%$ ) and early teens (frequent $60 \%$, infrequent $26 \%$ ). It was also observed that an evident number of respondents in the Lower and Middle-Middle Income group regularly shared TVC information with their 
contacts. The same phenomena are observed amongst the School and College students as well. So, it can be concluded that sharing of TVC information is an attitude adopted by urban teens irrespective of gender, age, income or education.

\begin{tabular}{|c|c|c|c|c|c|c|c|c|c|c|c|}
\hline \multirow{2}{*}{$\begin{array}{l}\text { Demographi } \\
\text { c Variables }\end{array}$} & \multirow{2}{*}{ Categories } & \multicolumn{2}{|c|}{ Total } & \multicolumn{2}{|l|}{ Yes } & \multicolumn{2}{|c|}{ No } & \multicolumn{2}{|c|}{ Sometimes } & \multicolumn{2}{|c|}{ Yes+ Sometimes } \\
\hline & & $\mathrm{f}$ & $\%$ & $\mathrm{f}$ & $\%$ & $\mathrm{f}$ & $\%$ & $\mathrm{f}$ & $\%$ & F & $\%$ \\
\hline All & Total & 300 & $100 \%$ & 165 & $55 \%$ & 51 & $17 \%$ & 84 & $28 \%$ & 249 & $83 \%$ \\
\hline \multirow{2}{*}{ Gender } & Male & 164 & $55 \%$ & 86 & $52 \%$ & 32 & $20 \%$ & 46 & $28 \%$ & 130 & $79 \%$ \\
\hline & Female & 136 & $45 \%$ & 79 & $58 \%$ & 19 & $14 \%$ & 38 & $28 \%$ & 117 & $86 \%$ \\
\hline \multirow{2}{*}{ Teens Class } & Early Teen & 137 & $46 \%$ & 82 & $60 \%$ & 19 & $14 \%$ & 36 & $26 \%$ & 118 & $86 \%$ \\
\hline & Late Teen & 163 & $54 \%$ & 83 & $51 \%$ & 32 & $20 \%$ & 48 & $29 \%$ & 131 & $80 \%$ \\
\hline \multirow{3}{*}{$\begin{array}{l}\text { Income } \\
\text { Group }\end{array}$} & $\begin{array}{l}\text { Lower- } \\
\text { Middle }\end{array}$ & 67 & $22 \%$ & 38 & $57 \%$ & 13 & $19 \%$ & 16 & $24 \%$ & 54 & $81 \%$ \\
\hline & Middle & 163 & $54 \%$ & 93 & $57 \%$ & 27 & $17 \%$ & 43 & $26 \%$ & 136 & $83 \%$ \\
\hline & $\begin{array}{l}\text { Upper- } \\
\text { Middle }\end{array}$ & 70 & $23 \%$ & 34 & $49 \%$ & 11 & $16 \%$ & 25 & $36 \%$ & 59 & $84 \%$ \\
\hline \multirow{3}{*}{ Institution } & School & 123 & $41 \%$ & 73 & $59 \%$ & 19 & $15 \%$ & 31 & $25 \%$ & 104 & $85 \%$ \\
\hline & College & 80 & $27 \%$ & 48 & $60 \%$ & 16 & $20 \%$ & 16 & $20 \%$ & 64 & $80 \%$ \\
\hline & University & 97 & $32 \%$ & 44 & $45 \%$ & 16 & $16 \%$ & 37 & $38 \%$ & 81 & $84 \%$ \\
\hline
\end{tabular}

Table 10: TVC Information Sharing Attitude

\subsection{Discussion and conclusions}

The study has observed that $70 \%$ of the respondents watch TV regularly, $25 \%$ occasionally and $5 \%$ never watches TV. The females are found to be a little more inclined to watching TV (97\%) than their male counterparts (93\%). Majority of the school going early teens (13-16 years) watch TV regularly $(84 \%)$ in comparison to $58 \%$ of college/university going late teens (16-19 years). But, quite a few (32\%) late teens watch TV occasionally in comparison to a few early teens $(16 \%)$. This is further validated by observing that school students watch more TV than college or university students. Income wise, it is observed that the lower-middle and middle-income group tends to watch TV more (97\% and $96 \%$ respectively) than the upper-middle income group (89\%).

Regarding popular TV programs about $41 \%$ found to prefer sports, $29 \%$ prefer drama serial, $21 \%$ prefer reality shows, $7 \%$ prefer news and only 3\% prefer talk shows. The females were more inclined to watching drama serials (57\%) and reality shows (26\%). Majority of the males prefer watching sports $(67 \%)$. Teens prefer watching sports more than anything else. A large portion of the early teens preferring to watch drama serials $(36 \%)$. As per income, all the three categories (lower middle, middle, upper middle) has given their best preference for sports $(45 \%, 39 \%, 41 \%)$ followed by drama serial $(30 \%, 33 \%$ $19 \%)$ and realty shows $(18 \%, 21 \%, 21 \%)$.

The statistic for sports watching remains highest at all level of educational status (school $41 \%$, college $43 \%$, and university $40 \%$ ); however, the school students watch more drama serials (41\%) than the college $(21 \%)$ and university students $(20 \%)$. In a nutshell, it was noticed that for targeting the late teens, school students, the middle-middle income group, and female consumers' attention, it would be better to broadcast TVC during drama serials and reality shows. On the contrary, to cover the largest male teen audience, it would be better to broadcast TVC during sports shows as the percentage of viewers of sports was the highest across all classifications.

The study noted that $71 \%$ of the respondents watch TV at night, $21 \%$ watch in the evening, $5 \%$ in the afternoon, and only $4 \%$ in the morning. Henceforth, it is very clear that for the urban youth's night can be defined as pick hour, the evening is semi pick hour, and afternoon and morning can be treated as an 
off-peak hour. It is more or less applicable across all the classifications. In order to get the most views of a TVC, it would be better to broadcast TVC in the evening and at night.

Regarding TVC watching pattern, the study revealed that 53\% watch TVC regularly, 36\% occasionally and $11 \%$ never watches TVC. Gender wise females $(90 \%)$ found to watch TVC a little more than males (88\%). The early teen respondents watch TVC more $(94 \%)$ than the late teen respondents $(85 \%)$. This is further validated when looking into the educational institution classification. Here it is observed that the school students watch more TVC (95\%) than the college (88\%) and university students $(83 \%)$. Also, the lower-middle and middle-income group tends to watch TVC more $(91 \%)$ than the uppermiddle income group (83\%). It is worth noting that the TVC watching pattern almost coincides with the TV watching pattern.

The study has also figured out that the majority (52\%) of the respondents watches the TVC as they are part of another program. Also, a substantial number (39\%) loves to watch TVC willingly because they enjoy it. Only a small (4\%) number of respondents watch TVC listening to others. As per different demographic characteristics (Gender, a teen class, income, institution), a similar pattern of responses are observed in the study. Among all the demographic groups, college students (66\%) seem to watch TVC mainly because it is inbuilt in another TV program. The college students also said to be enjoying it comparatively less $(21 \%)$.

The study suggested that the respondents like the funny $(37 \%)$ and informative (33\%) commercials more than the thematic $(15 \%)$ ads. About $15 \%$ mentioned that they are indifferent of any specific type of TVC. Gender wise the females like the funny $(40 \%)$ TVC more than the males (35\%); whereas the males like the informative TVC (40\%) more than the females (33\%). The study further noted that early teens prefer both funny and informative TVCs (40\% and 39\%) more than the late teens (34\% and 29\%). A significant portion of late teens $(25 \%)$ found to prefer all three types of TVCs.

Income wise the middle class (44\%) found to prefer funny TVCs more than the lower-middle (27\%) and upper-middle $(30 \%)$ income groups. Furthermore, the middle income $(37 \%)$ found to prefer informative TVCs the most. Upper-middle (34\%) and middle (31\%) income group. To get higher viewership, the marketer should concentrate on funny and/or informative TVC making. Education wise, school children (41\%) found to love the funny TVCs the most followed by informative (36\%) and thematic (21\%) TVCs. Similar pattern is observed for college students (Funny: 38\%, Informative: 30\%, Thematic: $14 \%)$. The university students are found to prefer almost equally informative (33\%) and funny (32\%) TVCs followed by thematic one (7\%). But, a significant portion (28\%) found to prefer all the three types of TVCs.

Regarding the influence of TVC on buying decision, 37\% responded positively, $31 \%$ claimed occasionally and $33 \%$ answered negatively. This indicates a significant influence of TVCs on purchase decisions. Gender wise, the females directly or indirectly $(69 \%)$ were more influenced by TVCs to take purchase decision than males $(64 \%)$. The early teens were more influenced by TVC $(47 \%)$ than the late teens $(30 \%)$. It is further validated by the findings that school students were more influenced by TVC $(50 \%)$ than the college $(28 \%)$ or university students $(30 \%)$. Furthermore, the upper-middle income group tends to be more influenced by TVCs $(79 \%)$ than the lower and middle-income group (63\% and $64 \%$ ) respectively. Hence, it can be concluded that irrespective of demographic features there is a strong influence of TVCs on buying decision.

In terms of final purchase, the study explored that a good number of respondents (35\%) frequently and infrequently $(15 \%)$ buy products watching TVCs. But the majority $(53 \%)$ mentioned that they do not make any direct purchase influenced by TVCs. Hence there is evidence of the difference between desire and action. Gender wise, the females $(38 \%+16 \%)$ are more influenced by TVCs to purchase than males $(28 \%+13 \%)$. The late teens are more influenced by TVC $(64 \%)$ than the early teens $(28 \%)$. It is further validated by the responses that college $(51 \%)$ and university students $(71 \%)$ are more influenced by TVC to purchase than the school students $(26 \%)$. Furthermore, the upper-middle income group purchases more influenced by TVCs (66\%) than the lower and middle-income group (39\% and $43 \%)$ respectively. Hence, it can be concluded that irrespective of demographic features there is a significant influence of TVCs to purchase products. 
The study regarded that the majority $(65 \%)$ of the respondents were influenced by models or celebrities to watch the TVC. Demographic variable wise (gender, a teen class, income group, and institution) similar trend is observed in the study. Also, within each of these demographic groups, not much difference is observed. However, this percentage is a little higher for the females $(66 \%)$, early teens $(69 \%)$, upper-middle income group (73\%), and school going children (70\%). Hence, we can conclude that there is an influence of models/celebrities among urban teens in watching TVCs.

It has been revealed by the research that a large portion of the respondents frequently (55\%) and infrequently (28\%) share TVC information with others while very few $(17 \%)$ has no sharing attitude. Demographic variable wise (gender, a teen class, income group, and institution) similar trend is observed in the study. Sharing attitude was more prominent among females (frequent 58\%, infrequent 28\%) and early teens (frequent $60 \%$, infrequent $26 \%$ ). It was also observed that a noticeable number of respondents in the lower and middle-income group, as well as the school and college students, took part in regularly sharing TVC information with their contacts. So, it can be said that sharing of TVC information is an attitude adopted by urban teens irrespective of gender, age, income or education.

Sharing TVC information is essentially word-of-mouth marketing. The segments who share information, share them for the TVCs that appeal to them. If a company invests in a TVC that appeals to the females, early teens, lower and middle-middle income group or school and college students, they are most likely to enjoy a higher impact from their investment. This is because, not only will they receive a large audience for their TVCs, they will also enjoy free word-of-mouth marketing from their audience.

\subsection{Limitations and direction for further research}

It is almost impossible for a single paper to cover each and every aspect of the research topic. Naturally, there are some limitations which are in turn, the scope for further research into the subject matter for other researchers. Prime delimitations and related research opportunities are briefed below:

The key objective of the research work is to target the urban teens of Bangladesh. The research work, however, has been conducted among the teens of Dhaka metropolitan city due to convenience, time and budget constraints and its strategic advantage. Since people from each and every corner of the country migrate to this city, Dhaka has become home of all the different classes of people who make up this country. Nevertheless, other metros and cities were not considered in the research work, where the scenario may be different in teenage buying behavior by watching TV and TVC. Moreover, rural teens were not considered in the research work. There is ample opportunity for the researchers to work with teens of other metros, cities and rural areas of Bangladesh. Bangladesh can be considered as a model developing country in the South Asian subcontinent. Based on this research paper, researchers can try to figure out if similar results can be found in other developing countries like Bangladesh.

This research is concerned with teen students who are the subset of the young demographic, age 10 to 24 . The buying behavior of young and teen segment is mostly similar considering the human cognitive development process. At the later stages of the young group, in the early twenties, TV and TVCs might affect individuals differently. Hence, there is a scope for further research on the larger youth demographic as a whole.

The research was designed in a way that it focuses on the middle-class socio-economic demography. This class comprises a large chunk of the total teenage population of the country. This class is also more exposed to Television media and TV commercials in general. Hence, the lower class and the upper class were not considered. As the lower-lower class teenage students may not have much access to televisions, the scenario may be very different for them. Similarly, the upper-class teenage students might be more inclined to digital media instead of the more traditional television media. Both the excluded groups can be observed and researched for a better understanding of their buying behavior which can be helpful for marketers in the future.

The research paper only focuses on TV commercials and their effects on the target group. On the other hand, other media vehicles like radio, outdoor campaign, digital media, and print media has a high influence on teenagers. So, researchers have a huge opportunity to further work with other media vehicles and figure out their respective effects on their buying behavior. 


\section{Recommendation and implication}

It has been revealed in the research that $95 \%$ of the respondents watch TV either regularly or occasionally. In terms of gender is it noted that females were more inclined to watch TV $(97 \%)$ than their counterparts $(93 \%)$. So, Television is still one of the most important media vehicles for business professionals especially brand builders to promote their brands among the middle-class urban teenagers of a developing country like Bangladesh.

To target the late teens, school students, the middle-income group, and female consumers' attention, it would be better to broadcast TVC during drama serials and reality shows. On the contrary, to cover the largest male teen audience, it would be better to broadcast TVCs during sports. This is because of the percentage of viewers of sports was the highest across all classifications.

It would be preferable for the brand builders to telecast TVCs in the evening and at night hours as they can get the most views. TVC.

To get higher viewership, the marketers need to concentrate on making funny and/or informative

If a company invests in a TVC that appeals to the groups comprising of females, early teens, lower and middle-middle income group or school and college students, they are most likely to enjoy a higher return on their investment. This is because, not only will they receive a larger audience for their TVCs, but also will enjoy free word-of-mouth marketing from their audience as they talk about it among themselves.

There is a high influence of models or celebrities among the urban teens in watching TVCs. While making TVCs, it is very important for marketers as well as creative firms (filmmakers) to endorse the right kind of models and celebrities.

In conclusion, for brand building and promotion, advertisement is the most important tool. Among all the different forms of advertisement, in this age of digital media, television advertisement remains the best media, especially in the context of Bangladesh and its middle-class society. From an early age, children are exposed to television and they are accustomed to watching television commercials on a daily basis. Children, while watching these TVCs subconsciously start wanting the products in advertisements and slowly but surely try to influence their parents to buy those products. As the children step into teenage life, they are more heavily influenced by TVCs. While teenagers spend less time watching television, and thereby television commercials than children, however, they are more aware of their conscious mind and know what they want to buy. Teenagers are more open to trying new products, to stay updated with the world, and of course to stand out among their peers. So, naturally, an enticing TVC greatly shapes and influences their buying behavior.

Notes

1 TVCs are any paid form of non-personal communication of ideas or products on the electronic media to end user

2 Funny topics are humorous, hilarious, amusing, comical and the like.

3 Informative topics are educational, revealing, instructive and the like.

4 Thematic topics are subject, topic, idea, theme, thesis, and argument based.

5 AIDA (attention, interest, desire, and action) is an acronym used in marketing and advertising, which helps marketing managers develop effective communication strategies and communicate with customers in a way that better responds to their needs and desires. Attention results into interest which results in desire and finally consumers go for action. There is a big difference in percentage between attention and action.

\section{References}

Abbas, Zamin R., \& Bari, A. (2011). Advertisement \& Islam: A Muslim World Perspective. Australian Journal of Business \& Management Research, 1(6), 152-1.

Abideen, Z. U., \& Saleem, S. (2011). Effective advertising \& its influence on consumer buying behavior. European Journal of Business \& Management, 3(3), 55-65.

Adiko, A. E. \& Adjei, D (2016). The Influence of Television Advertisement on the Youth Purchasing Behavior.

Ahmed, B. (2013). Impact of brand image \& advertisement on consumer buying behavior. World Applied Sciences Journal, 23(1), 117-122. 
Anjum, B., Iram, A. \& Naheed (2015). Impact of Television Advertisement on Consumer Buying Behavior: The Moderating Role of Religiosity in the context of Pakistan, IIJSR, Vol.1 No.3 pp. 36-48.

Anwar, S. (2012). Young consumers' attitude towards television advertisements in the internet age. ZENITH International Journal of Multidisciplinary Research, 2(4).

Barve, G., Sood, A., Nithya, S. \&Virmani, T (2015). Effects of advertising on youth (age group 13-19 years age). Journal of mass communication $\mathcal{E}$ journalism, 5; 260.

BBS (2011). Bangladesh Bureau of Statistics, Population Monograph of Bangladesh, BBS, Government of Bangladesh.

BES (2015), Bangladesh Education Statistic 2015, Bangladesh Bureau of Educational Information \& Statistics, Ministry of Education.

Farooq, Q., Shafique, N., Khurshid, M.M., \& Ahmad, N. (2015). Impact of comic factor in TV ads on buying behavior of university students. International Letters of Social E Humanistic Sciences, 8(1), 12-20.

Jain, S. (2014).Impact of advertisement on the consumer behavior a case study of some selected FMCG products in union territory of Chandigarh.

Kaliyaperumal, N. \& Rajakrisnan, S. V. (2015). Impact of Television Advertisement on Buying Behavior Regarding Customer Satisfaction \& Commitment in Nagapattinam District. International Journal of Advanced Scientific Research E Development, Volume - 2, Issue - 2 (April - Jan'15), 86 - 93.

Lawan, L.A. and Zanna, R. (2013), Evaluation of Socio-Cultural Factors Influencing Consumer Buying Behavior of Clothes in Borno Sate, Nigeria, International Journal of Basic and Applied Science, VO1 01, No. 03, pp. 519-529.

Patel, G. \& Jain, R. (2015).Impact of TV advertisement on youth buying behavior. Pioneer journal of IT $\mathcal{E}$ Management.

PRB (2016).World Population Data Sheet 2006, Population Reference Bureau, USAID, USA.

Ramya, N. and SA Mohamed Ali, M. SA., (2016), Factors affecting consumer buying behavior, International Journal of Applied Research, 2(10): 76-80.

Rani, N, \& Sharma, V. (2014). Impact of television commercial on purchasing behavior of masses. International journal of science $\mathcal{E}$ research (IJSR).ISSN (online): 2319-7264, Television of Bangladesh. Bangladesh.com. Archived from the original on December 2008.Retrieved 2008-12-18.

Rehman, F., Nawaz, T., Khan, A., \& Hyder, S. (2014). How Advertising Affects the Buying Behavior of Consumers in Rural Areas: A Case of Pakistan.

Vani, G., Babu, M. G., \& Panchanatham, N. (2011). Consumer Buying Behavior Model for Toothpastes. Indian Journal of Marketing, 41(10).

Virvilaite, R., \& Matuleviciene, M. (2013). The impact of shocking advertising to consumer buying behavior. Economics EManagement, 18(1), 134-141.

Walter, T., \& Davie, G. (1998).There ligiosity of women in the modern West. British Journal of Sociology, 640-660.

Waqas, A., Aslam, N. M., Bilal, M., \& Umair, M. (2014). Impact of TV advertisement on Children Buying Behavior. International Journal of Humanities E Social Science, Vol. 4 No. 2 [Special Issue], 246-261.

Zaltman, G. (2003). How customers think: Essential insights into the mind of the market: Harvard Business Press.

Zaltman, G., Dotlich, D. L., \&Cairo, P. C. (2003). How customers think: Audio-Tech Business Book Summaries. 